\title{
Experimental Models of Acute Lung Injury in the Newborns
}

\author{
D. MOKRA ${ }^{1,2}$, A. CALKOVSKA ${ }^{1,2}$ \\ ${ }^{1}$ Biomedical Center Martin, Jessenius Faculty of Medicine in Martin, Comenius University in \\ Bratislava, Martin, Slovakia, ${ }^{2}$ Department of Physiology, Jessenius Faculty of Medicine in Martin, \\ Comenius University in Bratislava, Martin, Slovakia
}

Received February 20, 2017

Accepted February 26, 2017

\begin{abstract}
Summary
Acute lung injury in the preterm newborns can originate from prematurity of the lung and insufficient synthesis of pulmonary surfactant. This situation is known as respiratory distress syndrome (RDS). In the term neonates, the respiratory insufficiency is related to a secondary inactivation of the pulmonary surfactant, for instance, by action of endotoxins in bacterial pneumonia or by effects of aspirated meconium. The use of experimental models of the mentioned situations provides new information on the pathophysiology of these disorders and offers unique possibility to test novel therapeutic approaches in the conditions which are very similar to the clinical syndromes. Herewith we review the advantages and limitations of the use of experimental models of RDS and meconium aspiration syndrome (MAS) and their value for clinics.
\end{abstract}

\section{Key words}

Acute lung injury • Newborn - Animal model • Surfactant depletion • Meconium aspiration

\section{Corresponding author}

D. Mokra, Biomedical Center Martin and Department of Physiology, Jessenius Faculty of Medicine in Martin, Comenius University in Bratislava, Mala Hora 4C, 03601 Martin, Slovakia. E-mail: mokra@jfmed.uniba.sk

\section{Introduction}

Acute lung injury (ALI) can originate from various pulmonary and extrapulmonary reasons and occur in all age groups. In neonates, ALI can arise from delayed adaptation or maladaptation to extra-uterine life, existing conditions such as surgical or congenital anomalies or from acquired conditions such as pulmonary infections occurring pre- or post-delivery (Gallacher et al. 2016). The general clinical picture of ALI in the newborn includes the respiratory distress with apnea, cyanosis, grunting, inspiratory stridor, nasal flaring, poor feeding, tachypnea, and retractions in the intercostal, subcostal, or supracostal spaces (Hermansen and Lorah 2007). ALI manifesting as the respiratory distress develops in approximately $7 \%$ of all infants, with the highest incidence in the preterm babies (30\%) followed by the post-term (20\%) and term babies (4\%) (Kumar and Bhat 1996). The incidence of the respiratory distress in the neonates may vary according to the regional differences in the quality of the perinatal health service and the study design.

The respiratory distress in the neonates is most frequently caused by transient tachypnea of the newborn (TTN), respiratory distress syndrome (RDS), meconium aspiration syndrome (MAS), infection (pneumonia or sepsis), various nonpulmonary causes (e.g. anemia, congenital heart disease etc.), persistent pulmonary hypertension of the newborn, or pneumothorax (Hermansen and Lorah 2007). In the epidemiological study conducted in India by Kumar and Bhat (1996), TTN was found to be the commonest ( $43 \%$ ) cause of the respiratory distress followed by infection (17\%), MAS (11\%), RDS ( $9 \%$ ), and birth asphyxia (3\%). However, the reason for the respiratory distress strongly depends on a gestational age of the infant. TTN is a common condition among both term and preterm babies, RDS was seen mostly among preterms, and MAS among term and post-term babies 
(Kumar and Bhat 1996). For instance, in the term neonates with gestational age of 37-41 weeks the overall incidence of mechanically ventilated TTN was $0.72 \%$, the incidence of RDS was $0.38 \%$ and the incidence of MAS was $0.61 \%$ (Gouyon et al. 2007). On the other hand, RDS affects one third of infants born at 28 to 34 weeks' gestation, but occurs in less than $5 \%$ of those born after 34 weeks' gestation (Hermansen and Lorah 2007).

\section{Pathophysiology, clinical picture treatment of ALI in the newborns}

and

Transient tachypnea of the newborn, also known as a retained fetal lung fluid syndrome, occurs in the term and late-preterm infants and represents about $40 \%$ of all cases of the neonatal respiratory distress (Kumar and Bhat 1996, Reuter et al. 2014). The largest risk factor for TTN is a delivery by cesarean section (CS), particularly by elective CS when mechanisms of the labor have nor commenced (Gallacher et al. 2016). TTN originates when the removal of the lung fluid after delivery is delayed. Normally after birth, fluid from the lung airspaces and airsacs is cleared. For this reason, late in gestation and before birth the chloride and fluidsecreting channels in the lung epithelium are reversed so that the fluid is removed from the lungs. There are several factors enhancing the fluid removal including the labor onset, a fetal thorax compression with uterine contractions, a release of fetal epinephrine in labor or antenatal corticosteroids (Elias and O'Brodowich 2006, Reuter et al. 2014). The clinical presentation of this relatively benign condition includes tachypnea with increased work of breathing immediately or within two hours after the birth, with diffuse parenchymal infiltrates, a ,wet silhouette" around the heart, or intralobar fluid accumulation on the chest radiography. The laboratory investigation shows mild respiratory acidosis and hypoxemia. The signs persist for 24 to $72 \mathrm{~h}$. For prevention of TTN, administration of antenatal steroids prior to elective $\mathrm{CS}$ could be considered, or to avoid elective CS prior to 38 weeks of gestation (Edwards et al. 2003). Management is supportive. Infants may require supplemental oxygen and continuous positive airway pressure (CPAP) to assist in maintaining alveolar integrity and driving fluid into circulation, but usually do not require mechanical ventilation (Reuter et al. 2014).

More severe form of the neonatal respiratory distress is respiratory distress syndrome of the newborn, also called hyaline membrane disease. This situation typically occurs in the premature neonates due to structural and functional lung immaturity, particularly in infants born before 28 weeks' gestation (Hermansen and Lorah 2007). However, RDS is diagnosed in about $7 \%$ of infants born $\geq 37$ weeks' gestation (Gallacher et al. 2016), as well. Due to deficiency of pulmonary surfactant the alveolar surface tension increases what results in alveolar atelectasis, decreased lung compliance, pulmonary vasoconstriction, and hypoperfusion (Holme and Chetcuti 2012). Proteinaceous fluid leaking through the injured alveolar-capillary membrane clots and forms hyaline membranes. Surfactant deficiency appears as diffuse fine granular infiltrates, air bronchograms and decreased lung volumes on the chest radiography (Reuter et al. 2014). Clinical signs include tachypnea, hypoxia, cyanosis, grunting, nasal flaring, retractions and other signs of respiratory distress immediately after the birth. Persistent RDS leads to bronchopulmonary dysplasia with typical chest radiography findings and chronic oxygen support. For prevention of RDS, antenatal steroids are given to mother to enhance maturation of the fetal lung and to promote surfactant production. Mild cases of RDS respond to supplemental oxygen and CPAP, more severe cases require endotracheal intubation and administration of exogenous surfactant with or without a need of mechanical ventilation (Gallacher et al. 2016). The course of RDS usually improves within 4 days as the infant begins to produce an endogenous surfactant (Reuter et al. 2014).

Meconium aspiration syndrome typically occurs in the term and post-term neonates. Meconiumstained amniotic fluid (MSAF) can be found in 10-15\% of all deliveries, however, MAS develops in 4-5\% of those cases (Cleary and Wiswell 1998). Normally, meconium (or the first stools of the newborn) is evacuated from the intestine within 2 days after the labor. However, due to intrauterine stress (e.g. in fetal hypoxemia) or stimulation of vagal nerve the fetus increases a blood flow through the vitally important organs via vasoconstriction in the splanchnic region. Because of intestinal ischemia the meconium can pass into the amniotic fluid. In addition, asphyxia stimulates respiratory movements of the fetus which become irregular and the fetus can aspirate amniotic fluid stained with meconium. MSAF can be aspirated during first breaths after the birth, as well. Meconium consists of amniotic fluid, desquamed epithelial cells, dermis, lanugo, vernix caseosa, mucus, bile acids and bile salts, bilirubin, cholesterol, free fatty acids, gastrointestinal 
enzymes including pancreatic phospholipase $\mathrm{A}_{2}$ etc. (Cleary and Wiswell 1998, Mokra and Mokry 2010). Many of these substances injure the lung cells and surfactant directly (Lopez-Rodriguez et al. 2011), but they can also induce the inflammatory response in the lung (Lindenskov et al. 2015, Kopincova and Calkovska 2016), or generate pulmonary vasoconstriction (Holopainen et al. 1998, Kuo and Chen 1999). Permeability through an injured alveolar-capillary membrane increases and lung edema is formed. Early after aspiration, particles of inhaled meconium obstruct the airways and increase the airway resistance. It results to alveolar atelectasis distally from the airway occlusion, to elevation in right-to-left pulmonary shunts and to hypoxemia, hypercapnia, and acidosis. With movement of meconium to periphery of the lungs, collapse of alveoli and small airways originates due to dysfunction of surfactant (Lopez-Rodriguez et al. 2011). This is followed by a decrease in lung compliance (Tyler et al. 1978), development of chemical pneumonia with neutrophil-mediated response (Salvesen et al. 2010, Kopincova and Calkovska 2016), and cell death due to apoptosis and necrosis (Vidyasagar and Zagariya 2008). The severity of the changes depends on the volume and concentration of aspirated meconium and a period of exposure to meconium. Chest radiography shows nonuniform, coarse, patchy infiltrates radiating from the hila into the periphery with areas of atelectasis or consolidation, or air-trapping (Cleary and Wiswell 1998, Swarnam et al. 2012). Historically, oro- and nasopharyngeal suctioning after delivery of the head but before delivery of the shoulders was performed in the meconium-stained infant, however, a routine suctioning on the perineum is no longer recommended as it did not reduce incidence of MAS. Endotracheal suctioning is limited to the depressed infants with low heart rate $(<100 \mathrm{bpm})$, poor muscle tone, and no positive spontaneous respiratory effort (Bhat and Vidyasagar 2012). Severe cases of MAS usually require oxygen supplementation, CPAP or mechanical ventilation. Further improvement can be reached with the use of exogenous surfactant and inhaled nitric oxide (NO), while there has been no sufficient evidence for the use of anti-inflammatory drugs including corticosteroids (Mokra and Mokry 2010, Swarnam et al. 2012).

The other reason for respiratory insufficiency in neonates is pneumonia. An infection could be of bacterial origin (usually caused by group $B$ streptococci, Staphylococcus aureus, Streptococcus pneumoniae, and gram-negative enteric rods), or more rarely of viral, fungal, spirochetal, or protozoan origin. Infants may acquire the pneumonia transplacentally, via infected amniotic fluid, via colonization at the time of birth, or nosocomially (Reuter et al. 2014, Gallacher et al. 2016). Clinical picture can have various manifestations including signs of respiratory distress and temperature instability. In bacterial pneumonia, the respiratory distress occurs hours to days after delivery as the infection takes time to develop. Chest radiography shows diffuse bilateral infiltrates with or without pleural effusions (Hermansen and Lorah 2007, Edwards et al. 2013). The neonatal pneumonia is a part of a generalized sepsis illness, therefore obtaining blood and cerebrospinal fluid cultures and initiating broad-spectrum antibiotic therapy is recommended for any symptomatic infant (Oh 2013). Regardless of the causal microorganism, infants require a supportive care and many of them need supplemental oxygen, CPAP or mechanical ventilation (Reuter et al. 2014).

\section{Rationale for the use of animal models}

Existing gaps in understanding the pathophysiology of the mentioned disorders and unsatisfactory response to some treatments in the subgroups of patients force the researchers to look for unknown interactions between the pathomechanisms and for testing of novel therapies. Animal models provide a valuable bridge between the patients and the laboratory. Since clinical studies bring fundamental descriptive information about the onset and evolution of the pathophysiological and inflammatory changes in the lung, hypotheses about mechanisms of the injury have been difficult to test in humans but can be easily tested in the animals. Animal models of ALI reproduce the mechanisms and consequences of ALI/ARDS in humans including the clinical, physiological, biological and pathological changes (Matute-Bello et al. 2008).

Although the criteria for ALI are well defined in humans (ARDS Definition Task Force 2012), these cannot be directly translated to experimental animals. From this reason, an Official American Thoracic Society Workshop concluded that the fundamental features of experimental ALI include:

- histological evidence of the tissue injury, such as accumulation of neutrophils in the alveolar and interstitial space, formation of hyaline membranes, presence of proteinaceous debris in the alveoli, thickening of the alveolar wall, evidence of 
hemorrhage, atelectasis etc.

- alteration of the alveolar-capillary membrane proven by increased extravascular lung water content, elevated concentration of total protein or of high molecular weight proteins (e.g. albumin, $\operatorname{IgM}$ ) in the BAL fluid, increased lung wet/dry weight ratio etc.

- presence of the inflammatory response, such as increased absolute number of neutrophils in the bronchoalveolar lavage (BAL) fluid, elevated lung myeloperoxidase (MPO) activity, increased concentrations of proinflammatory cytokines in the lung tissue or BAL fluid, increase in procoagulatory activity, levels of complement factors and matrix metalloproteinases, expression of adhesion molecules etc.

- evidence of the physiological dysfunction, such as hypoxemia with arterial partial pressure of oxygen $\left(\mathrm{PaO}_{2}\right)<60 \mathrm{mmHg}$ (or $8 \mathrm{kPa}$ ), ratio of $\mathrm{PaO}_{2}$ and fraction of inspired oxygen $\left(\mathrm{FiO}_{2}\right)<200 \mathrm{mmHg}$ (or $26.7 \mathrm{kPa}$ ), or oxygen saturation of hemoglobin $\left(\mathrm{SpO}_{2}\right)<90 \%$, increased alveolar-arterial oxygen difference $\left[(\mathrm{Aa}) \mathrm{DO}_{2}\right]$, increased spontaneous minute ventilation or respiratory rate (Matute-Bello et al. 2011).

To determine if the lung injury of a sufficient extent has occurred in animals, the Workshop recommended that at least three of the four ,main features" of ALI should be identified and preferably, one or two additional measurements to confirm the results. However, not all of the measurements listed should be performed in every study (Matute-Bello et al. 2011).

\section{General limitations of the animal models}

Animal models can reliably reproduce the acute damage to the epithelial and endothelial barriers and the acute inflammatory response in the lung. If the injury should evolve over time, i.e. if the animals are supported for prolonged periods, the information from such models has a high value for transfer to clinical practice. Nevertheless, human lungs can be affected by the mechanisms involved in the primary illness (e.g. sepsis) and/or they can be affected by therapeutical modalities used for supportive care (e.g. mechanical ventilation). Furthermore, the course of the clinical syndrome is influenced by hereditary factors, susceptibility to the triggering agents, concomitant diseases etc. (Matute-Bello et al. 2008).

Other factors which can limit the value of the results obtained from the animal models are the differences between the species. There are several unique characteristics of animal species, i.e. species differences in an innate immune response (differences in Toll-like receptors, in a mononuclear phagocyte system, in a production of nitric oxide, in chemokines and chemokine receptors) and differences in an animal size which should be considered in animal modeling (MatuteBello et al. 2008).

\section{Animal models of neonatal ALI}

Considering pulmonary surfactant, the respiratory distress in the neonates occurs from two main reasons: 1) from primary deterioration of surfactant, such as surfactant depletion due to its insufficient production in immature neonates or due to production of incompletely functioning surfactant in several genetically-conditioned surfactant disorders, and 2) from secondary deterioration of normally produced and functioning surfactant caused by inactivation by any inhibitor (e.g. by aspirated meconium, leaking plasma proteins, oxidants, gastric content etc.) (Calkovska et al. 2013). In the following subsections, one model representing each of these situations has been introduced.

\section{Model of surfactant depletion induced by repetitive saline lung lavage (model of RDS)}

The model of surfactant depletion is standardly performed in anesthetized animals (rabbits, pigs, dogs, sheep etc.) after a short period of stabilization (e.g. $15 \mathrm{~min}$ ) during which the animal is oxygenventilated. Then, the measurement of initial values of the respiratory parameters is done and blood samples are taken for determination of the blood gases. Model of surfactant depletion is induced by instillation of warmed $\left(37-39^{\circ} \mathrm{C}\right)$ isotonic saline of the volume $10-30 \mathrm{ml} / \mathrm{kg}$ through the endotracheal cannula what is followed by its immediate suctioning. This procedure is repeated until a target hypoxemia, e.g. $200 \mathrm{mmHg}$ (or $26.7 \mathrm{kPa}$ ) or $300 \mathrm{mmHg}$ ( or $40 \mathrm{kPa}$ ), is reached whereas the period of restoration lasting several minutes between the individual lavages should be left. When the target hypoxemia is measured in two control measurements (e.g. $5 \mathrm{~min}$ and $15 \mathrm{~min}$ ) after the lavage, the model is considered to be prepared and the experiment continues with administration of any pharmacological therapy or with use of any mode of artificial ventilation (Rotta et al. 
2001, Calkovska et al. 2005, Ronchi et al. 2011, Ronchi et al. 2012, Fioretto et al. 2012, Kosutova et al. 2016a, Kosutova et al. 2016b, Mokra et al. 2016). To prepare a lavage model with stable deterioration of the lung functions, a low dose of detergent, e.g. Tween 80 , can be added into the lavage fluid to further inactivate the lung surfactant (Musch et al. 2004), or the lung lavage can be done by diluted detergent, e.g. Triton X100 diluted in saline (Otahal et al. 2016).

Saline lung lavage removes a significant portion of surfactant what results into increase of the alveolar surface tension and impairment of the alveolar host defense (Matute-Bello et al. 2008, Wang et al. 2008). Lung lavage enhances alveolar collapse and increases the likelihood of mechanical injury to the alveolar walls during repetitive opening and closure in ventilation. In our recent experiments, lung lavage with saline at a dose of $30 \mathrm{ml} / \mathrm{kg}$ repeated 6-12 times decreased lung compliance of about $30-35 \%$ compared to initial values and increased intrapulmonary shunting as shown by higher lung venous shunt and A-a gradient (Kosutova et al. 2016a, Mokra et al. 2016). These changes caused a profound hypoxemia expressed as decreased $\mathrm{PaO}_{2}$, $\mathrm{PaO}_{2} / \mathrm{FiO}_{2}$ (or $\mathrm{PF}$ ratio), $\mathrm{SpO}_{2}$ and increased oxygenation index, and hypercapnia and acidemia. Deterioration in the gas exchange after induction of ALI was presented also in other studies (Rotta et al. 2001, Vangerow et al. 2001, Calkovska et al. 2005, Ronchi et al. 2011, Ronchi et al. 2012, Bang et al. 2012). Respiratory distress which occurs after repetitive saline lung lavage requires a use of higher ventilatory pressures to supply a sufficient gas exchange in the injured animals (Calkovska et al. 2005, Mokra et al. 2016, Kosutova et al. 2016a).

In our studies, the lavage procedure triggered neutrophil migration into the alveoli as indicated by significantly higher total count of cells and by higher percentage of neutrophils in the BAL fluid $4 \mathrm{~h}$ after induction of ALI in comparison to healthy controls (Kosutova et al. 2016a, Kosutova et al. 2016b, Mokra et al. 2016) (Fig. 1). Migration of polymorphonuclears (PMN), particularly of neutrophils, into the lung is associated with decrease of their count in the peripheral blood (Mokra et al. 2016). Comparable results were reported in a similar model of ALI (Noda et al. 2003, Waragai et al. 2007, Menk et al. 2015) and also in patients with ARDS (Nakos et al. 1998) in an early phase of the disorder. Our experiments showed increased concentrations of pro-inflammatory cytokines IL-1 $\beta$, IL-6, IL-8 (Kosutova et al. 2016a, Kosutova et al. 2016b,
Mokra et al. 2016), and TNF- $\alpha$ (Mokra et al. 2016) in the lung tissue of animals with lavage-induced ALI compared to healthy controls. Elevated levels of cytokines in the lung within several hours after induction of ALI were previously demonstrated by other authors (Noda et al. 2003, Waragai et al. 2007, Menk et al. 2015), too. Cytokines IL-1 $\beta$, IL-8 and TNF- $\alpha$ significantly increased their concentrations also in the plasma (Mokra et al. 2016) (Fig. 2). These cytokines have been considered for sensitive biomarkers of ALI also in pediatric and adult patients with ARDS (Bhargava and Wendt 2012, Mokra and Kosutova 2015, Orwoll and Sapru 2016). In the premature neonates, changes in cytokines were associated with an increased risk of chronic lung disease (Huang et al. 2000, Speer 2003, An et al. 2004). In addition to cytokines, increased expression of inducible nitric oxide synthase (iNOS) mRNA in the lung tissue, higher concentration of nitrites/nitrates in the plasma and slightly elevated concentrations of thiobarbituric acid-reactive substances (TBARS) were detected, as well (Kosutova et al. 2016b). The on-going inflammation, oxidative stress and other factors (Lang et al. 2002) led to injury of epithelial cells as proven by higher concentrations of endogenous secretory receptor for advanced glycation end-products (esRAGE), a marker od epithelial injury (Uchida et al. 2006), and also to injury of endothelial cells, as shown by increased sphingosine-1phosphate receptor 3 (S1PR3), a marker of epithelial injury (Singleton et al. 2006), in the lung tissue of ALI animals compared to healthy controls (Kosutova et al. 2016b, Mokra et al. 2016). The last two mentioned substances and many other biochemical biomarkers are of importance for a prognosis prediction in pediatric and adult patients with ALI (Sun et al. 2012, Orwoll and Sapru 2016), as well.

In histological investigation, alveolar collapse changing with overdistended regions and peribronchial edema have been described. Alveolar-capillary membrane becomes thickened with destruction and desquamation of epithelial and endothelial cells, necrosis of alveolar type I cells, and injury to basement membrane (Imai et al. 2001). In our studies, significantly higher occurrence of atelectasis and PMN infiltration and slightly higher occurrence of hemorrhagia and emphysema resulted in higher value of total lung injury score (Mokra et al. 2016, Kosutova et al. 2016a). Similar histopathological changes early after induction of ALI were observed also by others (Ronchi et al. 2011, Kamiyama et al. 2014). Additional injury to the lung is 
A ๑C-RDS —RDS ๑C-MAS DMAS

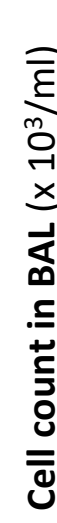

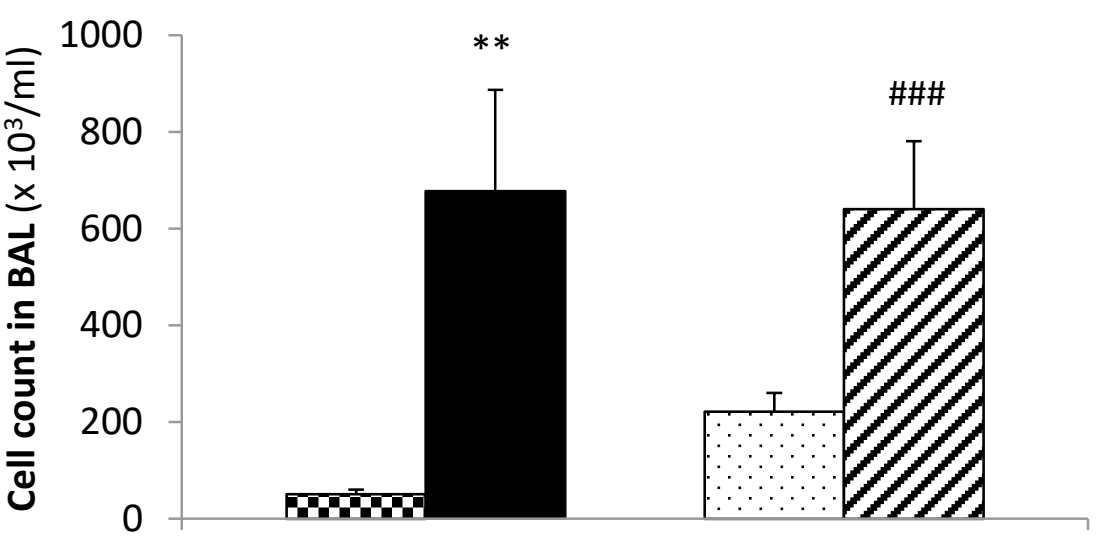

Fig. 1. Total (A) and differential (B) cell count in the BAL fluid of rabbits with a model of RDS induced by repetitive saline lung lavage (RDS group) and in healthy controls to RDS (C-RDS group), and of rabbits with a model of MAS induced by intratracheal meconium instillation (MAS group) and in healthy controls to MAS (C-MAS group). Statistical differences between groups: for RDS vs. C-RDS ${ }^{* *} \mathrm{P}<0.01,{ }^{* * *} \mathrm{P}<0.001$; for MAS vs. C-MAS \# $\mathrm{P}<0.01$, \#\#\# $\mathrm{P}<0.001$

\section{B $\square$ C-RDS RDS $\square$-MAS DMAS}

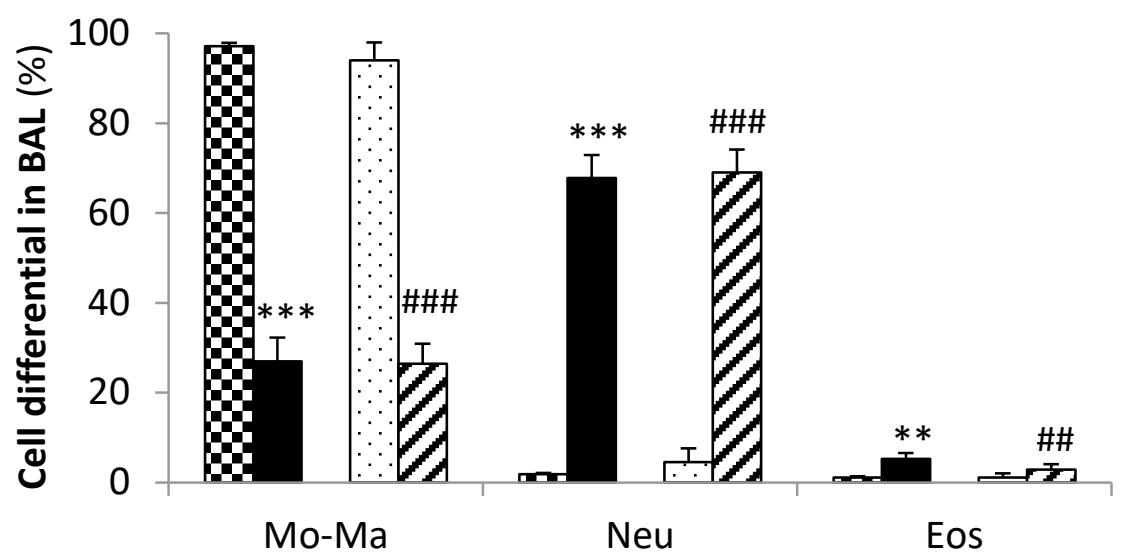

mediated through increased apoptosis of epithelial cells (Galani et al. 2010). In our experiments, increased apoptotic index of epithelial cells detected by TUNEL methods serving for in situ labeling of DNA strand breaks (Kosutova et al. 2016a, Kosutova et al. 2016b, Mokra et al. 2016), higher concentration of caspase-3, an enzyme responsible for execution of cell death, in the lung tissue measured by ELISA methods (Kosutova et al. 2016b, Mokra et al. 2016) and increased in situ activity of caspase-3 visualized by immunohistochemical methods (Mokra et al. 2016, Kosutova et al. 2016a) have suggested detectable apoptotic changes already $4 \mathrm{~h}$ after the insult. These findings are in agreement with the literature sources. DNA damage in the lung tissue determined by a comet assay was observed $4 \mathrm{~h}$ after lavage-induced ALI in rabbits (Ronchi et al. 2012). In an early phase of ARDS in adults and infants, decreased size, condensation of chromatin, and DNA fragmentation in pneumocytes were demonstrated (Bardales et al. 1996, Bem et al. 2007). Elevated markers of apoptosis including TUNEL-labeled DNA strand breaks and caspase-3 were also found in the lung tissue from patients who died from ALI/ARDS (Albertine et al. 2002). On the other hand, apoptosis of neutrophils in ALI is delayed what causes their longer persistence at a site of injury and further deterioration of the tissue (Galani et al. 2010). The above mentioned mechanisms contributed to a damage to alveolar-capillary lining as shown by increased protein concentration in the BAL fluid (Mokra et al. 2016) and accumulation of the liquid in the lung tissue indicated by higher value of lung wet-dry ratio compared to healthy controls (Kosutova et al. 2016a, Mokra et al. 2016) (Fig. 3). 
A

$\square \mathrm{C}-\mathrm{RDS} \square \mathrm{RDS} \square \mathrm{C}-\mathrm{MAS} \square \mathrm{MAS}$

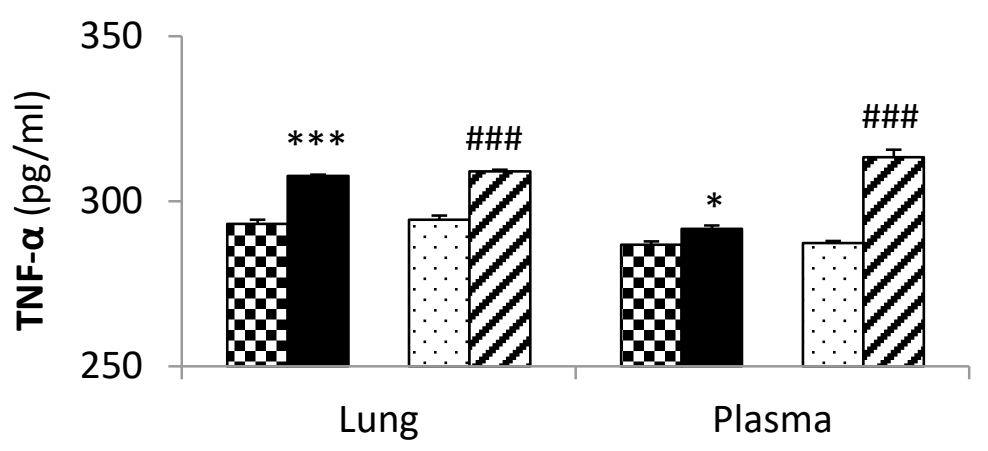

B

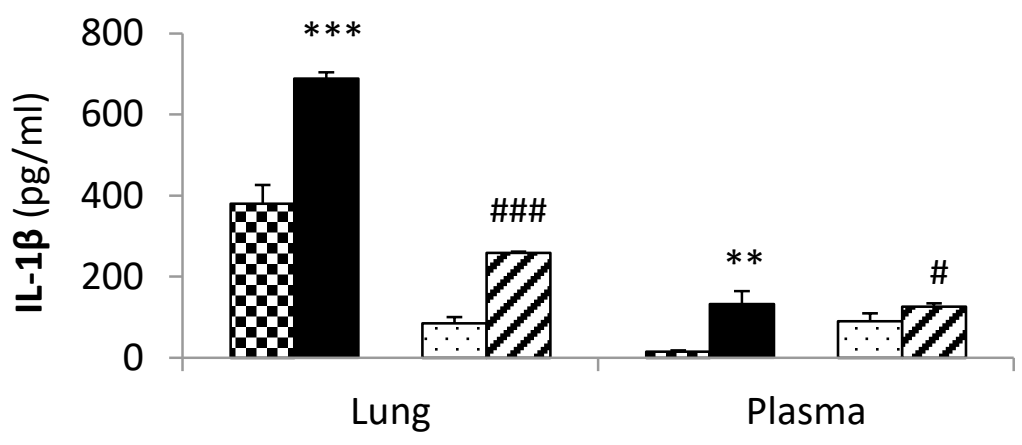

C aC-RDS RDS $\square$ C-MAS DMAS

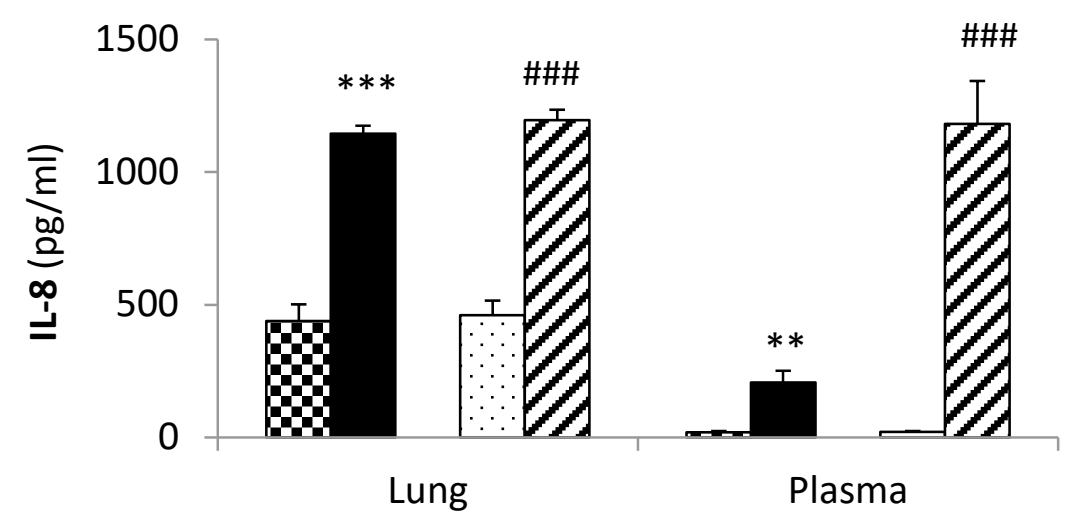

Fig. 2. Concentrations of tumor necrosis factor (TNF)-a (A), interleukin (IL)-1 $\beta$ (B) and IL-8 (C) in the lung tissue homogenates and blood plasma of rabbits with a model of RDS induced by repetitive saline lung lavage (RDS group) and in healthy controls to RDS (C-RDS group), and of rabbits with a model of MAS induced by intratracheal meconium instillation (MAS group) and in healthy controls to MAS (C-MAS group). Statistical differences between groups: for RDS vs. C-RDS ${ }^{*} \mathrm{P}<0.05$, ${ }^{* *} \mathrm{P}<0.01,{ }^{* * *} \mathrm{P}<0.001$; for MAS vs. C-MAS \#\# $\mathrm{P}<0.001$.
Data from our experiments and from studies of other authors show that the model of surfactant depletion by repetitive saline lung lavage simulates to a sufficient extent the situation in the premature neonates with surfactant deficiency and lung injury. Although in these model young-to-adult animals, particularly rabbits are commonly used, the model is generally accepted for this purpose and different kinds of therapies have been tested using these models. Even there are several advantages of the use of older than neonatal animals. The body weight, diameter of the airways, and lung compliance of rabbits or piglets are very close to those in the neonates what allows to realize artificial ventilation with comparable values of ventilatory parameters to those in neonates. Therefore, this model has been considered for an optimum possibility for testing of different ventilation strategies (Matute-Bello et al. 2008). In addition, the researchers can obtain blood samples of a sufficient volume repetitively during the experiment for measurement of the blood gases and other parameters which express an effectiveness of the used ventilation or other therapy. On the other hand, use of older animals than neonatal pups in this model might reduce a direct transfer of the results into the clinics. 


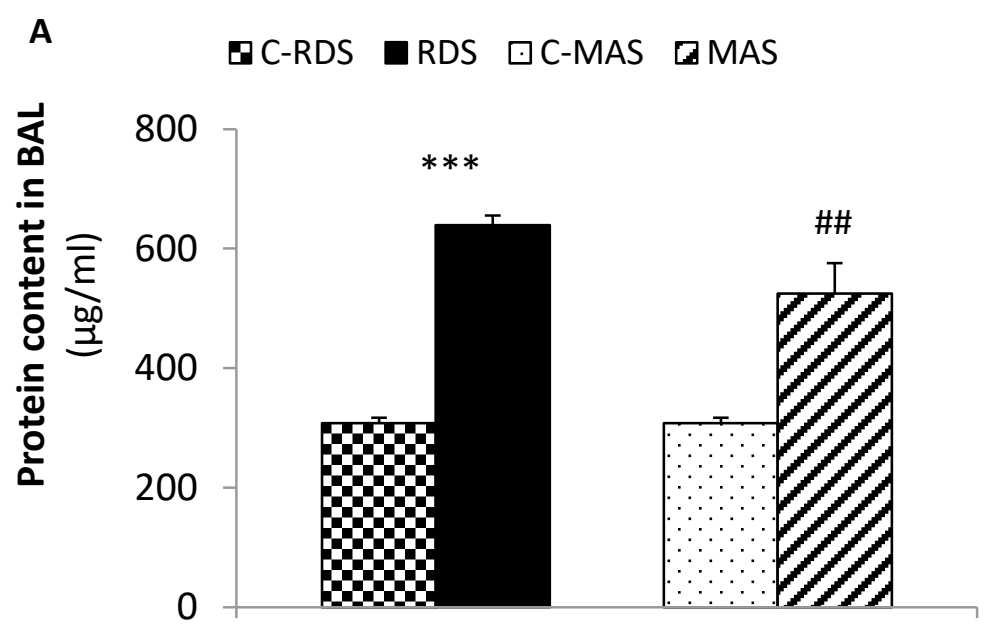

Fig. 3. Total protein content in the BAL fluid (A) and wet-dry lung weight ratio (B) in rabbits with a model of RDS induced by repetitive saline lung lavage (RDS group) and in healthy controls to RDS (C-RDS group), and of rabbits with a model of MAS induced by intratracheal meconium instillation (MAS group) and in healthy controls to MAS (C-MAS group). Statistical differences between groups: for RDS vs. C-RDS ${ }^{* * *} \mathrm{P}<0.001$; for MAS vs. C-MAS \#\# $\mathrm{P}<0.01,{ }^{\# \# \#} \mathrm{P}<0.001$.

B $\square C-R D S \square R D S \square C-M A S$ MAS

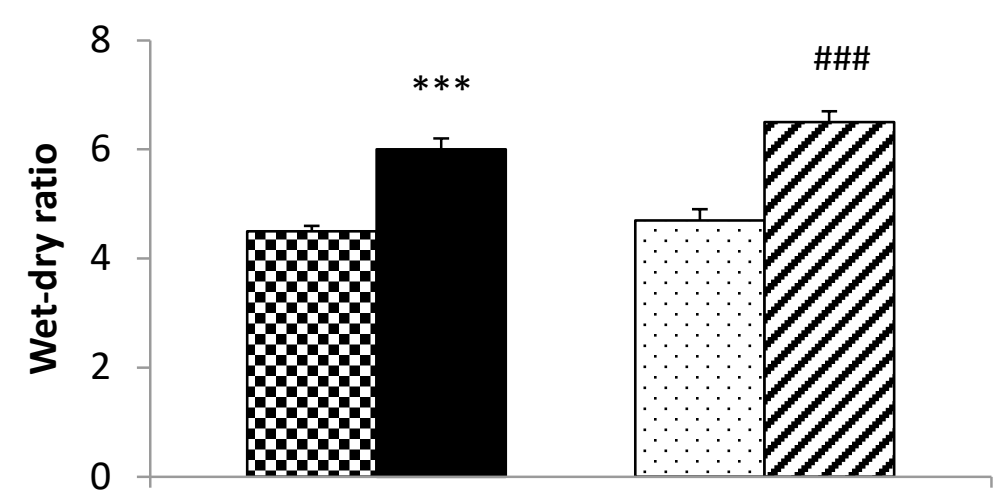

\section{Model of meconium aspiration syndrome induced by intratracheal instillation of meconium (model of MAS)}

Model of MAS is usually elicited in anesthetized animals by intratracheal instillation of a suspension of meconium. The meconium is taken from diapers of healthy neonates, is pooled and lyophilized in very low temperatures by a lyophilizator. Lyophilized meconium powder is then suspended in a pre-heated saline $\left(37^{\circ} \mathrm{C}\right.$, $0.9 \% \mathrm{NaCl}$ ) to a required concentration. According to the animal species and design of experiment, various combinations of meconium concentrations and dose volumes can be used. The meconium concentration of $25 \mathrm{mg} / \mathrm{ml}$ which represents about $10 \%$ of the original concentration of meconium makes a model of MAS with accentuated alveolar component of the syndrome with predominant surfactant dysfunction and inflammation (Sun et al. 1994, Mokra et al. 2007, Mikolka et al. 2013, Mokra et al. 2015, Li et al. 2015). On the other hand, instillation of 20 or $25 \%$ concentrations of meconium generates the model with accentuation of the airway obstruction (Holopainen et al. 1999, Hummler et al. 2001, Robinson and Roberts 2002, Shekerdemian et al. 2004). Before administration, meconium suspension can be filtered through gauze or a blotting paper to separate large meconium particles, or can be administered as nonfiltered. The later possibility resembles better the situation of meconium aspiration in the neonates; however, it is associated with increase in $\mathrm{PaCO}_{2}$ because of significant airway obstruction by meconium particles (Tyler et al. 1978). Various animal species have been utilized for creation of the MAS model: piglets (Kuo and Chen 1999, Aaltonen et al. 2005, Castellheim et al. 2005, Colvero et al. 2008), rabbits (Krause et al. 1998, Lam et al. 2000, Vidyasagar and Zagariya 2008, Zagariya et al. 2010), rats (Calkovska et al. 1999, Turhan et al. 2012), or rarely lambs (Rey-Santano et al. 2011) and mice (Khan et al. 2002a).

The intratracheal instillation of meconium in rabbits in our studies caused a decrease in dynamic lung compliance of around 45\% (Mokra et al. 2007, 
Calkovska et al. 2008, Mikolka et al. 2013, Mokra et al. 2015) and of more than $50 \%$ in the studies by other authors (Robinson and Roberts 2002, Li et al. 2015). Serious decline in the lung compliance after meconium instillation was observed also in other animal species (Wiswell et al. 1994, Cochrane et al. 1998, Castellheim et al. 2005, Zagariya et al. 2010, Rey-Santano et al. 2011, Renesme et al. 2013). Furthermore, administration of meconium significantly increased right-to-left pulmonary shunts, probably due to sustained perfusion of alveoli behind the meconium-obstructed bronchioles (Tyler et al. 1978, Holopainen et al. 1998). Intrapulmonary shunts elevated from $<10 \%$ before meconium to $40 \%$ or more early after meconium instillation (Krause et al. 1998, Mokra et al. 2007, Calkovska et al. 2008, Mikolka et al. 2013). Changes in the lung compliance and shunting resulted into rapid and persistent decrease in $\mathrm{PaO}_{2}$ and worsening in other parameters of oxygenation, such as $\mathrm{PF}$ ratio, OI, $\mathrm{SpO}_{2}$ etc. (Cochrane et al. 1998, Robinson and Roberts 2002, Tølløfsrud et al. 2002, Lindenskov et al. 2005, Castellheim et al. 2005, Mokra et al. 2007, Colvero et al. 2008, Calkovska et al. 2008, Rey-Santano et al. 2011, Turhan et al. 2012, Renesme et al. 2013, Mikolka et al. 2013, Kopincova et al. 2014, Li et al. 2015). Due to significant obstruction of the airways by meconium, higher values of $\mathrm{PaCO}_{2}$ accompanied by lower arterial $\mathrm{pH}$ have been detected (Robinson and Roberts 2002, Aaltonen et al. 2005, Lindenskov et al. 2005, Mokra et al. 2007, Colvero et al. 2008, Rey-Santano et al. 2011, Renesme et al. 2013, Kopincova et al. 2014, Li et al. 2015), as well. Deterioration in the gas exchange increases requirement for ventilation, as indicated by higher values of mean airway pressure after meconium instillation compared to values before meconium (Mokra et al. 2007, Calkovska et al. 2008, Tølløfsrud et al. 2002, Robinson and Roberts 2002, Renesme et al. 2013, Mikolka et al. 2013, Li et al. 2015).

In our studies, instillation of meconium significantly increased total number of cells and percentage of neutrophils, and slightly increased a percentage of eosinophils in the BAL fluid $5 \mathrm{~h}$ after meconium instillation compared to healthy controls (Mokry et al. 2006, Mokra et al. 2007, Kopincova et al. 2014, Mokra et al. 2015, Mikolka et al. 2016a, Mikolka et al. 2016b) (Fig. 1). Similar results were observed also by other authors (Khan et al. 2002a, Li et al. 2015). The presence of meconium triggers an activation of various inflammatory systems (cytokines, complement, arachidonic acid metabolites, reactive oxygen species
(ROS), NO, transcription factors etc.) in the lung what generates a complex pro-inflammatory appearance (Lindenskov et al. 2015). In the meconium-instilled animals, increased concentrations of pro-inflammatory cytokines (TNF- $\alpha$, IL-1 $\beta$, IL- 8 etc.) in the lung tissue, BAL fluid or in the plasma were detected (Lindenskov et al. 2005, Castellheim et al. 2005, Vidyasagar and Zagariya 2008, Zagariya et al. 2010, Turhan et al. 2012, Mikolka et al. 2013, Kopincova et al. 2014, Li et al. 2015, Mikolka et al. 2016b) (Fig. 2). The mentioned results are consistent with clinical findings (Cayabyab et al. 2007, Okazaki et al. 2008).

Meconium is a potent activator of a complement which is likely associated with systemic inflammatory response and oxidative burst (Castellheim et al. 2005). Furthermore, exposure to meconium enhances production of NO and its derivatives (Fontanilla et al. 2008), and triggers a significant oxidative stress leading to peroxidation of lipids (demonstrated by TBARS) and proteins (expressed by 3-nitrotyrosine, dityrosine, lysinelipid peroxidation products etc.) in the lung (Mokra et al. 2007, Mokra et al. 2015, Mikolka et al. 2016a, Mikolka et al. 2016b) and increases the oxidation markers also in the plasma (Kopincova et al. 2014, Mokra et al. 2015, Mikolka et al. 2016a). Intensive oxidation after meconium instillation was demonstrated also by Li et al. (2015) who found higher levels of malondialdehyde (MDA) in the BAL fluid and higher MPO activity in the lung tissue compared to controls. These results are consistent with studies performed on neonates where increased levels of cord blood plasma MDA, a marker of lipid peroxidation, and 8-hydroxy-2-deoxyguanosine (8-OH-dG), a marker of oxidative DNA damage, were found in the full-term and late-preterm neonates born through MSAF (Bandyopadhyay et al. 2017). Besides changes in the lung and plasma, evidence of oxidative injury was found also in the brain (Aaltonen et al. 2005). Other deleterious effects are associated with activation of the arachidonic-acid pathway. Higher phospholipase $\mathrm{A}_{2}$ activity detected in the meconium and meconiuminstilled lung suggests that meconium itself is a source of this enzyme and that its presence in the lung contributes to inflammation, surfactant dysfunction and cell apoptosis (Holopainen et al. 1999, Vidyasagar and Zagariya 2008). In addition, increased expression of cyclooxygenase-2 (COX-2) in the lung, and elevated prostaglandin $\mathrm{E}_{2}$ in the BAL fluid and in the plasma were found in meconiuminstilled animals (Kytölä et al. 2003, Li et al. 2015), and enhanced release of thromboxane $\mathrm{A}_{2}\left(\mathrm{TXA}_{2}\right)$ in the 
airway epithelial cells (Khan et al. 2002b). The vasoconstriction effect of hypoxemia, meconium bile acids, cytokines, leukotrienes, and $\mathrm{TXA}_{2}$ on the pulmonary vasculature is further emphasized by higher production of endothelin-1 (Kuo and Chen 1999). Increased reactivity of tracheal and lung tissue strips to bronchoconstriction mediators demonstrated in the meconium-instilled animals (Mokra et al. 2007, Mokry et al. 2006) can predispose to long-term respiratory sequelae such as wheezing and exercise-induced bronchospasm in infants who had overcome MAS (Vázquez Nava et al. 2006).

The complex action of the mentioned factors damages the alveolar-capillary membrane and increases a leak of proteinaceous liquid into the lung as expressed by higher protein content in the BAL fluid or tracheal aspirate (Wiswell et al. 1994, Zagariya et al. 2010, Turhan et al. 2012, Li et al. 2015) and higher wet-dry lung weight ratio (Mokra et al. 2007, Li et al. 2015, Mokra et al. 2015, Mikolka et al. 2016b) (Fig. 3). Hand in hand with injury to alveolar cells the deterioration in synthesis and function of pulmonary surfactant can be detected. Exposure to meconium caused a decrease in total phospholipid phosphorus levels in airway fluid samples (Wiswell et al. 1994, Lindenskov et al. 2005) and an increase in the surface tension of the tracheal aspirate (Wiswell et al. 1994, Cochrane et al. 1998). In our study, measurement by a capillary surfactometer showed a worsening in the surface properties of surfactant in BAL fluid of the meconium-instilled animals compared to values from the healthy controls (Mokra et al. 2013). Several hours after meconium instillation, lungs macroscopically exhibit a marked atelectasis, with dark red, non-expanded areas in at least $80 \%$ of the lung and small rims of expanded lung existed in the apical regions, presumably due to a failure of the meconium to reach these areas. Histological investigation shows large areas of atelectasis, dense infiltration of edema and inflammatory cells, primarily PMN, together with alveolar hemorrhage and thickening of the alveolar wall (Wiswell et al. 1994, Cochrane et al. 1998, Lam et al. 2000, Renesme et al. 2013, Li et al. 2015). In addition, meconium causes an early apoptosis of the lung cells, as previously demonstrated by various detection methods (Holopainen et al. 1999, Vidyasagar and Zagariya 2008, Zagariya et al. 2010).

As presented in this subsection, animal models of MAS have significantly contributed to elucidation of the pathomechanisms of the syndrome. In addition, these models have been used for pre-clinical testing of various therapeutical approaches. Of course, use of neonatal animals immediately after the labor is of advantage in elaboration of the MAS models. Such models simulate the aspiration of meconium on the background of postnatal changes of the lung from liquid-filled to air-filled organ (Sun et al. 1993). However, due to technical and ethical difficulties associated with this procedure, several days up to several-weeks-old animals have been often used instead of neonatal animals. On the other hand, piglets and young-to-adult rabbits have similar diameter of the airways and similar body weights (i.e. $2-4 \mathrm{~kg}$ ) to those in the neonates. From this reason, utilization of several-weeks-old or adult animals (particularly piglets and rabbits) can be advantageous if various modes of artificial ventilation are performed (Wiswell et al. 1994, Renesme et al. 2013, Mikusiakova et al. 2015) or if treatments are intratracheally delivered (exogenous surfactant, inhaled NO, corticosteroids etc.) (Lam et al. 2000, Shekerdemian et al. 2004, Mokra et al. 2007, Colvero et al. 2008, Calkovska et al. 2008, Mikolka et al. 2013).

\section{Conclusions}

Several types of animal models can be used to simulate the pathological changes in the acutely injured lungs of the neonates. However, no single animal model reproduces all the characteristics of ALI in humans, and most of the existing animal models are relevant for only limited aspects of ALI in humans. In spite of these limitations, animal models represent a valuable tool for better understanding the pathophysiology of acute respiratory distress in the neonates and provide an excellent pre-clinical background for searching the novel therapeutical strategies.

\section{Conflict of Interest}

There is no conflict of interest.

\section{Acknowledgements}

This work was supported by the project „Biomedical Center Martin“, ITMS code: 26220220187, the project is co-financed from EU sources; and by projects APVV-0435-11 and APVV-15-0075, and grants VEGA 1/0305/14 and VEGA 1/0469/16. 


\section{References}

AALTONEN M, SOUKKA H, HALKOLA L, KALIMO H, HOLOPAINEN IE, KÄÄPÄ PO: Meconium aspiration induces neuronal injury in piglets. Acta Paediatr 94: 1468-1475, 2005.

ALBERTINE KH, SOULIER MF, WANG Z, ISHIZAKA A, HASHIMOTO S, ZIMMERMAN GA, MATTHAY MA, WARE LB: Fas and fas ligand are up-regulated in pulmonary edema fluid and lung tissue of patients with acute lung injury and the acute respiratory distress syndrome. Am J Pathol 161: 1783-1796, 2002.

AN H, NISHIMAKI S, OHYAMA M, HARUKI A, NARUTO T, KOBAYASHI N, SUGAI T, KOBAYASHI Y, MORI M, SEKI K, YOKOTA S: Interleukin-6, interleukin-8, and soluble tumor necrosis factor receptor-I in the cord blood as predictors of chronic lung disease in premature infants. Am J Obstet Gynecol 191: 1649-1654, 2004.

ARDS DEFINITION TASK FORCE, RANIERI VM, RUBENFELD GD, THOMPSON BT, FERGUSON ND, CALDWELL E, FAN E, CAMPOROTA L, SLUTSKY AS: Acute respiratory distress syndrome: the Berlin Definition. JAMA 307: 2526-2533, 2012.

BANDYOPADHYAY T, BHATIA BD, KHANNA HD: A study of oxidative stress in neonates delivered through meconium-stained amniotic fluid. Eur J Pediatr 176: 317-325, 2017.

BANG JO, HA SI, CHOI IC: The effect of positive-end expiratory pressure on oxygenation during high frequency jet ventilation and conventional mechanical ventilation in the rabbit model of acute lung injury. Korean J Anesthesiol 63: 346-352, 2012.

BARDALES RH, XIE SS, SCHAEFER RF, HSU SM: Apoptosis is a major pathway responsible for the resolution of type II pneumocytes in acute lung injury. Am J Pathol 149: 845-852, 1996.

BEM RA, BOS AP, MATUTE-BELLO G, VAN TUYL M, VAN WOENSEL JB: Lung epithelial cell apoptosis during acute lung injury in infancy. Pediatr Crit Care Med 8: 132-137, 2007.

BHARGAVA M, WENDT CH: Biomarkers in acute lung injury. Transl Res 159: 205-217, 2012.

BHAT R, VIDYASAGAR D: Delivery room management of meconium-stained infant. Clin Perinatol 39: 817-831, 2012.

CALKOVSKA A, DANKO J, JAVORKA K, LASABOVA Z, MATASOVA K, MOKRA D, SIVAKOVA J, SVECOVA I, ZIBOLEN M: Pulmonary Surfactant - from Laboratory to Patient (in Slovak). Osveta, Martin, 2013, 222 p.

CALKOVSKA A, MOKRA D, DRGOVA A, ZILA I, JAVORKA K: Bronchoalveolar lavage with pulmonary surfactant/dextran mixture improves meconium clearance and lung functions in experimental meconium aspiration syndrome. Eur J Pediatr 167: 851-857, 2008.

CALKOVSKA A, SEVECOVA-MOKRA D, JAVORKA K, PETRASKOVA M, ADAMICOVA K: Exogenous surfactant administration by asymmetric high-frequency jet ventilation in experimental respiratory distress syndrome. Croat Med J 46: 209-217, 2005.

CALKOVSKA A, SUN B, CURSTEDT T, RENHEIM G, ROBERTSON B: Combined effects of high-frequency ventilation and surfactant treatment in experimental meconium aspiration syndrome. Acta Anaesthesiol Scand 43: 135-145, 1999.

CASTELLHEIM A, LINDENSKOV PH, PHARO A, AAMODT G, SAUGSTAD OD, MOLLNES TE: Meconium aspiration syndrome induces complement-associated systemic inflammatory response in newborn piglets. Scand J Immunol 61: 217-225, 2005.

CAYABYAB RG, KWONG K, JONES C, MINOO P, DURAND M: Lung inflammation and pulmonary function in infants with meconium aspiration syndrome. Pediatr Pulmonol 42: 898-905, 2007.

CLEARY GM, WISWELL TE: Meconium-stained amniotic fluid and the meconium aspiration syndrome. An update. Pediatr Clin North Am 45: 511-529, 1998.

COCHRANE CG, REVAK SD, MERRITT TA, SCHRAUFSTÄTTER IU, HOCH RC, HENDERSON C, ANDERSSON S, TAKAMORI H, OADES ZG: Bronchoalveolar lavage with KL4-surfactant in models of meconium aspiration syndrome. Pediatr Res 44: 705-715, 1998. 
COLVERO MO, FIORI HH, FIORI RM, LUZ JH, DE PAULA D, OPPERMANN C, PITREZ PM, DA SILVA VD, COLVERO AP: Bronchoalveolar lavage plus surfactant in a piglet model of meconium aspiration syndrome. Neonatology 93: 188-192, 2008.

DAVEY AM, BECKER JD, DAVIS JM: Meconium aspiration syndrome: physiological and inflammatory changes in a newborn piglet model. Pediatr Pulmonol 16: 101-108, 1993.

EDWARDS MO, KOTECHA SJ, KOTECHA S: Respiratory distress of the term newborn infant. Paediatr Respir Rev 14: 29-36, 2013.

ELIAS N, O'BRODOWICH H: Clearance of fluid from airspaces of newborns and infants. Neoreviews 7: e88, 2006.

FIORETTO JR, CAMPOS FJ, RONCHI CF, FERREIRA AL, KUROKAWA CS, CARPI MF, MORAES MA, BONATTO RC, DEFAVERI J, YEUM KJ: Effects of inhaled nitric oxide on oxidative stress and histopathological and inflammatory lung injury in a saline-lavaged rabbit model of acute lung injury. Respir Care 57: 273-281, 2012.

FONTANILLA R, ZAGARIYA A, VIDYASAGAR D: Meconium-induced release of nitric oxide in rabbit alveolar cells. J Perinatol 28 (Suppl 3): S123-S126, 2008.

GALANI V, TATSAKI E, BAI M, KITSOULIS P, LEKKA M, NAKOS G, KANAVAROS P: The role of apoptosis in the pathophysiology of Acute Respiratory Distress Syndrome (ARDS): an up-to-date cell-specific review. Pathol Res Pract 206: 145-150, 2010.

GALLACHER DJ, HART K, KOTECHA S: Common respiratory conditions of the newborn. Breathe (Sheff) 12: 30-42, 2016.

GOUYON JB, RIBAKOVSKY C, FERDYNUS C, QUANTIN C, SAGOT P, GOUYON B; BURGUNDY PERINATAL NETWORK: Severe respiratory disorders in term neonates. Paediatr Perinat Epidemiol 22: 22-30, 2008.

HERMANSEN CL, LORAH KN: Respiratory distress in the newborn. Am Fam Physician 76: 987-994, 2007.

HOLME N, CHETCUTI P: The pathophysiology of respiratory distress syndrome in neonates. Paediatr Child Health 22: 507-512, 2012.

HOLOPAINEN R, AHO H, LAINE J, PEURAVUORI H, SOUKKA H, KÄÄPÄ P: Human meconium has high phospholipase A2 activity and induces cellular injury and apoptosis in piglet lungs. Pediatr Res 46: 626-632, 1999.

HOLOPAINEN R, SOUKKA H, HALKOLA L, KÄÄPÄ P: Meconium aspiration induces a concentration-dependent pulmonary hypertensive response in newborn piglets. Pediatr Pulmonol 25: 107-113, 1998.

HUANG HC, YANG MY, HUANG CB, YANG KD: Profiles of inflammatory cytokines in bronchoalveolar lavage fluid from premature infants with respiratory distress disease. J Microbiol Immunol Infect 33: 19-24, 2000.

IMAI Y, NAKAGAWA S, ITO Y, KAWANO T, SLUTSKY AS, MIYASAKA K: Comparison of lung protection strategies using conventional and high-frequency oscillatory ventilation. J Appl Physiol (1985) 91: 1836-1844, 2001.

KAMIYAMA J, JESMIN S, SAKURAMOTO H, SHIMOJO N, ISLAM MM, KHATUN T, OKI M, KAWANO S, MIZUTANI T: Assessment of circulatory and pulmonary endothelin-1 levels in a lavage-induced surfactantdepleted lung injury rabbit model with repeated open endotracheal suctioning and hyperinflation. Life Sci 118: 370-378, 2014.

KHAN AM, ELIDEMIR O, EPSTEIN CE, LALLY KP, XUE H, BLACKBURN M, LARSEN GL, COLASURDO GN: Meconium aspiration produces airway hyperresponsiveness and eosinophilic inflammation in a murine model. Am J Physiol Lung Cell Mol Physiol 283: L785-L790, 2002a.

KHAN AM, LALLY KP, LARSEN GL, COLASURDO GN: Enhanced release of thromboxane A(2) after exposure of human airway epithelial cells to meconium. Pediatr Pulmonol 33: 111-116, $2002 \mathrm{~b}$.

KOPINCOVA J, CALKOVSKA A: Meconium-induced inflammation and surfactant inactivation: specifics of molecular mechanisms. Pediatr Res 79: 514-521, 2016.

KOPINCOVA J, MOKRA D, MIKOLKA P, KOLOMAZNIK M, CALKOVSKA A: N-acetylcysteine advancement of surfactant therapy in experimental meconium aspiration syndrome: possible mechanisms. Physiol Res $\mathbf{6 3}$ (Suppl 4): S629-S642, 2014. 
KOSUTOVA P, MIKOLKA P, BALENTOVA S, ADAMKOV M, KOLOMAZNIK M, CALKOVSKA A, MOKRA D: Intravenous dexamethasone attenuated inflammation and influenced apoptosis of lung cells in an experimental model of acute lung injury. Physiol Res 65 (Suppl 5): S663-S672, 2016a.

KOSUTOVA P, MIKOLKA P, KOLOMAZNIK M, BALENTOVA S, CALKOVSKA A, MOKRA D: Effects of S-nitroso-N-acetyl-penicillamine (SNAP) on inflammation, lung tissue apoptosis and iNOS activity in a rabbit model of acute lung injury. Adv Exp Med Biol 935: 13-23, $2016 \mathrm{~b}$.

KRAUSE MF, LIENHART HG, HABERSTROH J, HOEHN T, SCHULTE-MÖNTING J, LEITITIS JU: Effect of inhaled nitric oxide on intrapulmonary right-to-left-shunting in two rabbit models of saline lavage induced surfactant deficiency and meconium instillation. Eur J Pediatr 157: 410-415, 1998.

KUMAR A, BHAT BV: Epidemiology of respiratory distress of newborns. Indian J Pediatr 63: 93-98, 1996.

KUO C, CHEN J: Effect of meconium aspiration on plasma endothelin-1 level and pulmonary hemodynamics in a piglet model. Biol Neonate 76: 228-234, 1999.

KYTÖLÄ J, KÄÄPÄ P, UOTILA P: Meconium aspiration stimulates cyclooxygenase-2 and nitric oxide synthase-2 expression in rat lungs. Pediatr Res 53: 731-736, 2003.

LAM BC, YEUNG CY, FU KH, WONG KY, CHAN FL, TSOI NS: Surfactant tracheobronchial lavage for the management of a rabbit model of meconium aspiration syndrome. Biol Neonate 78: 129-138, 2000.

LANG JD, MCARDLE PJ, O'REILLY PJ, MATALON S: Oxidant-antioxidant balance in acute lung injury. Chest 122 (Suppl 6): 314S-320S, 2002.

LI AM, ZHANG LN, LI WZ: Amelioration of meconium-induced acute lung injury by parecoxib in a rabbit model. Int J Clin Exp Med 8: 6804-6812, 2015.

LINDENSKOV PH, CASTELLHEIM A, AAMODT G, SAUGSTAD OD: Meconium induced IL-8 production and intratracheal albumin alleviated lung injury in newborn pigs. Pediatr Res 57: 371-377, 2005.

LINDENSKOV PH, CASTELLHEIM A, SAUGSTAD OD, MOLLNES TE: Meconium aspiration syndrome: possible pathophysiological mechanisms and future potential therapies. Neonatology 107: 225-230, 2015.

LOPEZ-RODRIGUEZ E, ECHAIDE M, CRUZ A, TAEUSCH HW, PEREZ-GIL J: Meconium impairs pulmonary surfactant by a combined action of cholesterol and bile acids. Biophys $J$ 100: 646-655, 2011.

MATUTE-BELLO G, DOWNEY G, MOORE BB, GROSHONG SD, MATTHAY MA, SLUTSKY AS, KUEBLER WM; ACUTE LUNG INJURY IN ANIMALS STUDY GROUP: An official American Thoracic Society workshop report: features and measurements of experimental acute lung injury in animals. Am J Respir Cell Mol Biol 44: 725-738, 2011.

MATUTE-BELLO G, FREVERT CW, MARTIN TR: Animal models of acute lung injury. Am J Physiol Lung Cell Mol Physiol 295: L379-L399, 2008.

MENK M, GRAW JA, STEINKRAUS H, HAEFEN CV, SIFRINGER M, SPIES CD, LACHMANN B, SCHWAIBERGER D: Characterization of inflammation in a rat model of acute lung injury after repeated pulmonary lavage. Exp Lung Res 41: 466-476, 2015.

MIKOLKA P, KOPINCOVA J, KOSUTOVA P, CIERNY D, CALKOVSKA A, MOKRA D: Lung inflammatory and oxidative alterations after exogenous surfactant therapy fortified with budesonide in rabbit model of meconium aspiration syndrome. Physiol Res 65 (Suppl 5): S653-S662, $2016 \mathrm{~b}$.

MIKOLKA P, KOPINCOVA J, TOMCIKOVA MIKUSIAKOVA L, KOSUTOVA P, ANTOSOVA M, CALKOVSKA A, MOKRA D: Effects of surfactant/budesonide therapy on oxidative modifications in the lung in experimental meconium-induced lung injury. $J$ Physiol Pharmacol 67: 57-65, 2016a.

MIKOLKA P, MOKRA D, KOPINCOVA J, TOMCIKOVA-MIKUSIAKOVA L, CALKOVSKA A: Budesonide added to modified porcine surfactant Curosurf may additionally improve the lung functions in meconium aspiration syndrome. Physiol Res 62 (Suppl 1): S191-S200, 2013.

MIKUSIAKOVA LT, PISTEKOVA H, KOSUTOVA P, MIKOLKA P, CALKOVSKA A, MOKRA D: Effects on lung function of small-volume conventional ventilation and high-frequency oscillatory ventilation in a model of Meconium aspiration syndrome. Adv Exp Med Biol 866: 51-59, 2015.

MOKRA D, DRGOVA A, KOPINCOVA J, PULLMANN R, CALKOVSKA A: Anti-inflammatory treatment in dysfunction of pulmonary surfactant in meconium-induced acute lung injury. Adv Exp Med Biol 756: 189-196, 2013. 
MOKRA D, DRGOVA A, MOKRY J, ANTOSOVA M, DURDIK P, CALKOVSKA A: N-acetylcysteine effectively diminished meconium-induced oxidative stress in adult rabbits. $J$ Physiol Pharmacol 66: 101-110, 2015.

MOKRA D, KOSUTOVA P, BALENTOVA S, ADAMKOV M, MIKOLKA P, MOKRY J, ANTOSOVA M, CALKOVSKA A: Effects of budesonide on the lung functions, inflammation and apoptosis in a saline-lavage model of acute lung injury. J Physiol Pharmacol 67: 919-932, 2016.

MOKRA D, KOSUTOVA P: Biomarkers in acute lung injury. Respir Physiol Neurobiol 209: 52-58, 2015.

MOKRA D, MOKRY J, DRGOVA A, PETRASKOVA M, BULIKOVA J, CALKOVSKA A: Intratracheally administered corticosteroids improve lung function in meconium-instilled rabbits. $J$ Physiol Pharmacol $\mathbf{5 8}$ (Suppl 5): 389-398, 2007.

MOKRA D, MOKRY J: Meconium Aspiration Syndrome: From Pathomechanisms $t$

o Treatment. Nova Biomedical Books, New York, 2010, $130 \mathrm{p}$.

MOKRY J, MOKRA D, ANTOSOVA M, BULIKOVA J, CALKOVSKA A, NOSALOVA G: Dexamethasone alleviates meconium-induced airway hyperresponsiveness and lung inflammation in rabbits. Pediatr Pulmonol 41: 55-60, 2006.

MUSCH G, HARRIS RS, VIDAL MELO MF, O'NEILL KR, LAYFIELD JD, WINKLER T, VENEGAS JG: Mechanism by which a sustained inflation can worsen oxygenation in acute lung injury. Anesthesiology 100: 323-330, 2004.

NAKOS G, KITSIOULI EI, TSANGARIS I, LEKKA ME: Bronchoalveolar lavage fluid characteristics of early intermediate and late phases of ARDS. Alterations in leukocytes, proteins, PAF and surfactant components. Intensive Care Med 24: 296-303, 1998.

NODA E, HOSHINA H, WATANABE H, KAWANO T: Production of TNF-alpha by polymorphonuclear leukocytes during mechanical ventilation in the surfactant-depleted rabbit lung. Pediatr Pulmonol 36: 475-481, 2003.

OH W: Early onset neonatal group B streptococcal sepsis. Am J Perinatol 30: 143-147, 2013.

OKAZAKI K, KONDO M, KATO M, KAKINUMA R, NISHIDA A, NODA M, TANIGUCHI K, KIMURA H: Serum cytokine and chemokine profiles in neonates with meconium aspiration syndrome. Pediatrics 121: e748-e753, 2008.

ORWOLL BE, SAPRU A: Biomarkers in pediatric ARDS: Future directions. Front Pediatr 4: 55, 2016.

OTAHAL M, MLCEK M, VITKOVA I, KITTNAR O: A novel experimental model of acute respiratory distress syndrome in pig. Physiol Res 65 (Suppl 5): S643-S651, 2016.

RENESME L, ELLEAU C, NOLENT P, FAYON M, MARTHAN R, DUMAS DE LA ROQUE E: Effect of high-frequency oscillation and percussion versus conventional ventilation in a piglet model of meconium aspiration. Pediatr Pulmonol 48: 257-264, 2013.

REUTER S, MOSER C, BAACK M: Respiratory distress in the newborn. Pediatr Rev 35: 417-428, 2014.

REY-SANTANO C, ALVAREZ-DIAZ FJ, MIELGO V, MURGIA X, LAFUENTE H, RUIZ-DEL-YERRO E, VALLS-I-SOLER A, GASTIASORO E: Bronchoalveolar lavage versus bolus administration of lucinactant, a synthetic surfactant in meconium aspiration in newborn lambs. Pediatr Pulmonol 46: 991-999, 2011.

ROBINSON TW, ROBERTS AM: Effects of exogenous surfactant on gas exchange and compliance in rabbits after meconium aspiration. Pediatr Pulmonol 33: 117-123, 2002.

RONCHI CF, DOS ANJOS FERREIRA AL, CAMPOS FJ, KUROKAWA CS, CARPI MF, DE MORAES MA, BONATTO RC, DEFAVERI J, YEUM KJ, FIORETTO JR: High-frequency oscillatory ventilation attenuates oxidative lung injury in a rabbit model of acute lung injury. Exp Biol Med (Maywood) 236: 1188-1196, 2011.

RONCHI CF, FIORETTO JR, FERREIRA AL, BERCHIERI-RONCHI CB, CORREA CR, KUROKAWA CS, CARPI MF, MORAES MA, YEUM KJ: Biomarkers for oxidative stress in acute lung injury induced in rabbits submitted to different strategies of mechanical ventilation. J Appl Physiol (1985) 112: 1184-1190, 2012.

ROTTA AT, GUNNARSSON B, FUHRMAN BP, HERNAN LJ, STEINHORN DM: Comparison of lung protective ventilation strategies in a rabbit model of acute lung injury. Crit Care Med 29: 2176-2184, 2001.

SALVESEN B, STENVIK J, ROSSETTI C, SAUGSTAD OD, ESPEVIK T, MOLLNES TE: Meconium-induced release of cytokines is mediated by the TRL4/MD-2 complex in a CD14-dependent manner. Mol Immunol 47: 1226-1234, 2010. 
SHEKERDEMIAN LS, RAVN HB, PENNY DJ: Interaction between inhaled nitric oxide and intravenous sildenafil in a porcine model of meconium aspiration syndrome. Pediatr Res 55: 413-418, 2004.

SINGLETON PA, DUDEK SM, MA SF, GARCIA JG: Transactivation of sphingosine 1-phosphate receptors is essential for vascular barrier regulation. Novel role for hyaluronan and CD44 receptor family. $J$ Biol Chem 281: 34381-34393, 2006.

SPEER CP: Inflammation and bronchopulmonary dysplasia. Semin Neonatol 8: 29-38, 2003.

SUN B, CURSTEDT T, ROBERTSON B: Surfactant inhibition in experimental meconium aspiration. Acta Paediatr 82: 182-189, 1993.

SUN B, HERTING E, CURSTEDT T, ROBERTSON B: Exogenous surfactant improves lung compliance and oxygenation in adult rats with meconium aspiration. J Appl Physiol (1985) 77: 1961-1971, 1994.

SUN X, SINGLETON PA, LETSIOU E, ZHAO J, BELVITCH P, SAMMANI S, CHIANG ET, MORENO-VINASCO L, WADE MS, ZHOU T, ET AL.: Sphingosine-1-phosphate receptor-3 is a novel biomarker in acute lung injury. Am J Respir Cell Mol Biol 47: 628-636, 2012.

SWARNAM K, SORAISHAM AS, SIVANANDAN S: Advances in the management of meconium aspiration syndrome. Int J Pediatr 2012: 359571, 2012.

TØLlØFSRUD PA, MEDBØ S, SOLAS AB, DREVON CA, SAUGSTAD OD: Albumin mixed with meconium attenuates pulmonary dysfunction in a newborn piglet model with meconium aspiration. Pediatr Res 52: 545-553, 2002.

TURHAN AH, ATICI A, MUŞLU N, POLAT A, HELVACI İ: The effects of pentoxifylline on lung inflammation in a rat model of meconium aspiration syndrome. Exp Lung Res 38: 250-255, 2012.

TYLER DC, MURPHY J, CHENEY FW: Mechanical and chemical damage to lung tissue caused by meconium aspiration. Pediatrics 62: 454-459, 1978.

UCHIDA T, SHIRASAWA M, WARE LB, KOJIMA K, HATA Y, MAKITA K, MEDNICK G, MATTHAY ZA, MATTHAY MA: Receptor for advanced glycation end-products is a marker of type I cell injury in acute lung injury. Am J Respir Crit Care Med 173: 1008-1015, 2006.

VANGEROW B, HÄFNER D, RUECKOLDT H, MARX G, OTT N, LEUWER M, FRERKING I, GERMANN PG: Effects of $\mathrm{C} 1$ inhibitor and $\mathrm{r}$-SP-C surfactant on oxygenation and histology in rats with lavage-induced acute lung injury. Intensive Care Med 27: 1526-1531, 2001.

VÁZQUEZ NAVA F, SALAS RAMÍREZ E, SÁNCHEZ NÚNCIO HR, SALDIVAR GONZÁLEZ AH, BELTRÁN SALDAÑA J, CADENA MATA D, PÉREZ RODŔIGUEZ P, PÉREZ MARTIN J, ALMEIDA VM, GUIDOS FOGELBACH G: Meconium aspiration syndrome, parental atopy and asthma symptoms in children under two years old. Rev Alerg Mex 53: 130-135, 2006.

VIDYASAGAR D, ZAGARIYA A: Studies of meconium-induced lung injury: inflammatory cytokine expression and apoptosis. J Perinatol 28 (Suppl 3): S102-S107, 2008.

WANG HM, BODENSTEIN M, MARKSTALLER K: Overview of the pathology of three widely used animal models of acute lung injury. Eur Surg Res 40: 305-316, 2008.

WARAGAI A, YAMASHITA H, HOSOI K, HOSHINA H, NODA E, YAN K, KAWANO T: High-frequency oscillation (HFO) prevents activation of NF-kappaB found with conventional mechanical ventilation (CMV) in surfactant-depleted rabbit lung. Pediatr Pulmonol 42: 440-445, 2007.

WISWELL TE, PEABODY SS, DAVIS JM, SLAYTER MV, BENT RC, MERRITT TA: Surfactant therapy and high-frequency jet ventilation in the management of a piglet model of the meconium aspiration syndrome. Pediatr Res 36: 494-500, 1994.

ZAGARIYA A, SIERZPUTOVSKA M, NAVALE S, VIDYASAGAR D: Role of meconium and hypoxia in meconium aspiration-induced lung injury in neonatal rabbits. Mediators Inflamm 2010: 204831, 2010. 